\title{
A NEW SPECIES OF INDIAN WATERMOULD SAPROLEGNIA
}

\author{
R.V. Gandhe and Anagha Kurne
}

Postgraduate Research Centre, Botany Department, Modern College of Arts, science and Commerce, Pune 411005, Maharashtra, India. E-mail: kanchangandhe@hotmail.com

\begin{abstract}
Water moulds were isolated from different ponds, ditches and lakes around Pune City. They were cultured and purified for identification. Among all the isolated genera, Achlya was dominant followed by Saprolegnia. A new species of Saprolegnia, isolated from the lake is described in this paper based on remarkable morphological irregularities in zoosporangia, gemmae, oogonia, oospores and antheridia. It is compared with the allied species S.anisospora de Bary and S.diclina Humphrey.
\end{abstract}

\section{Keywords}

Morphometry, new description, oomycota, Saprolegnia anomalies sp. nov., zoosporic fungi

\section{Introduction}

During a Ph.D. dissertation of biological screening of fresh water bodies in and around the Pune City, Maharashtra State, India, aquatic fungi were isolated. A total of 8 genera and 13 species were isolated during rainy and winter seasons from different closed water bodies such as ponds, ditches and lakes. Amongst these isolated genera, the genus Achlya with its six species was found dominant and was very frequently isolated from the different closed bodies; an interesting species of Saprolegnia was repeatedly isolated from the Katraj Lake. This isolated species showed remarkable morphological irregularities in zoosporangia, oogonia, oospores, antheridia and gemmae to the established species. Morphometrical observations of the present species showed some similarities to the species Saprolegnia anisospora and S. diclina, but based on remarkable morphological differences a new species is proposed.

\section{Materials and Methods}

General survey of different water bodies such as ponds, lakes, in and around the Pune City was undertaken to establish five water-sampling stations for regular monthly sample collections. The samples were collected in the morning at around $1000 \mathrm{hr}$ from the selected sites in aseptic conditions in sterilized polythene bottles and brought to the laboratory for further investigations. Water temperature and $\mathrm{pH}$ were measured on the sites at the time of collection using standard thermometer and portable $\mathrm{pH}$ meter, respectively. The samples were placed in sterile distilled water in sterilized petri dishes containing several halves of sterile hemp seeds, Cannabis sativa L. as baits (Butler, 1907) and incubated at room temperature $25^{\circ} \mathrm{C}$ $28^{\circ} \mathrm{C}$. The growth of the culture was observed at regular intervals of time. Cultures were identified using monographs and relevant literature (Coker, 1923; Johnson, 1956; Sparrow, 1960,1968,1973; Seymour, 1970; Dick, 1973; Dayal \& Usha Kiran, 1988; Khulbe, 2001).

Saprolegnia anomalies sp. nov.

(Figures 1-22)

\section{Material examined}

30.xi. 2001, Katraj Lake, Pune, leg. A. Kurne, Culture deposited in the Germ Plasm Collection Centre for Zoosporic Fungi, Modern College, Botany Department, Pune 5.

\section{Etymology}

The proposed species is named because of remarkable morphological variations and irregularities in the gemmae, zoosporangia, oogonia and oospores compared to the allied species.

\section{Diagnostic features}

Mycellis densum, cultura in seminibus Cannabis sativus L., hyalinus, grossus, circa 1cm diam. Hyphae amphus basi ad 55-87 $\mu \mathrm{m}$ in diam. Gemmae abunduns, irregularis, globosus ad subglobosus, stipitatus ad sine stipitatus, terminalis ad

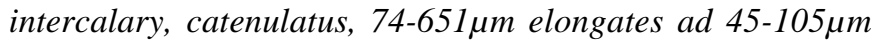
diam. Zoosporanga plura, frequens, elongata, cylindratis vel

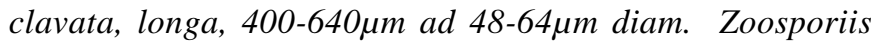
liberate per lateralibus pappilus et efformans eureticulus, sporae in cysts,9-11 $\mu$ m diam. Oogoniis plura, sphaerica, subsphaerica, frequens elongata, cylindratis vel clavata, longa 


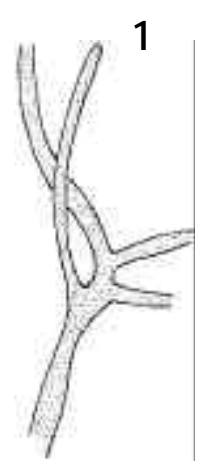

$\overline{100 \mu \mathrm{m}}$

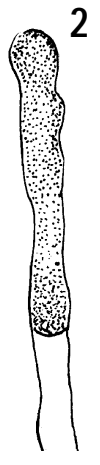

$\overline{100 \mu \mathrm{m}}$

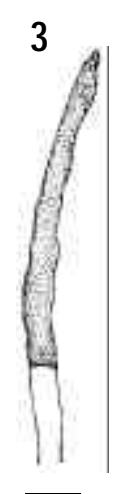

$\overline{100 \mu \mathrm{m}}$

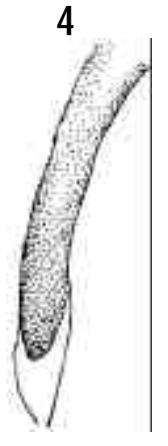

$100 \mu \mathrm{m}$
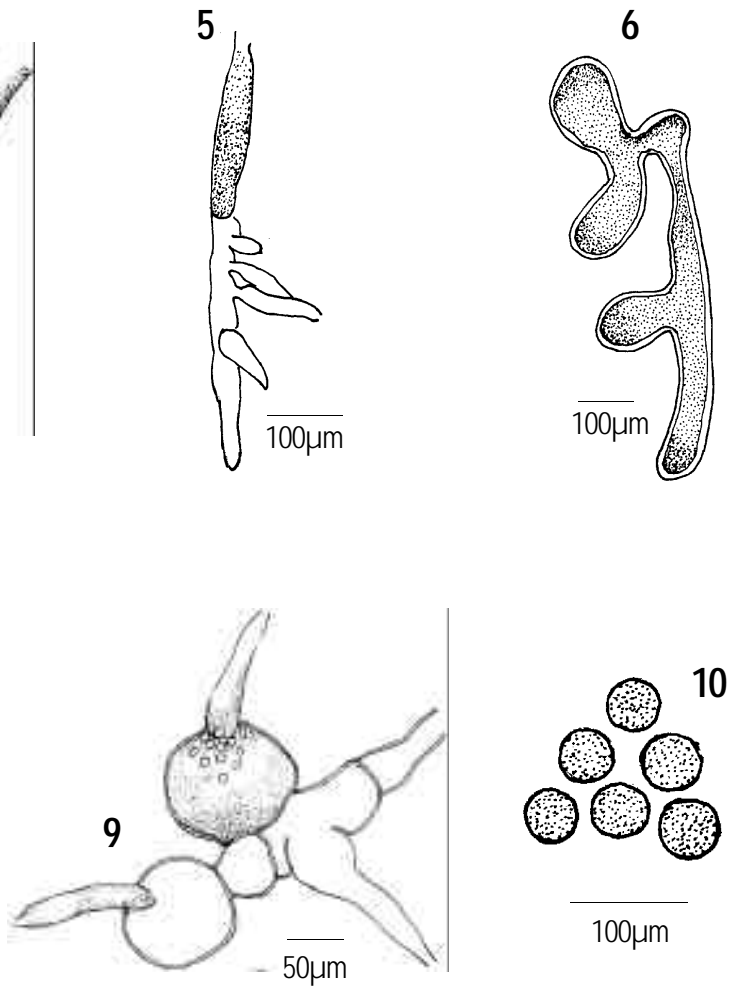
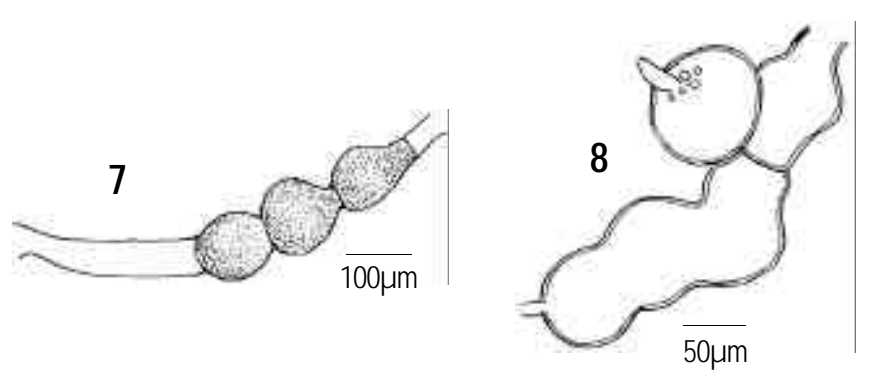

12

13
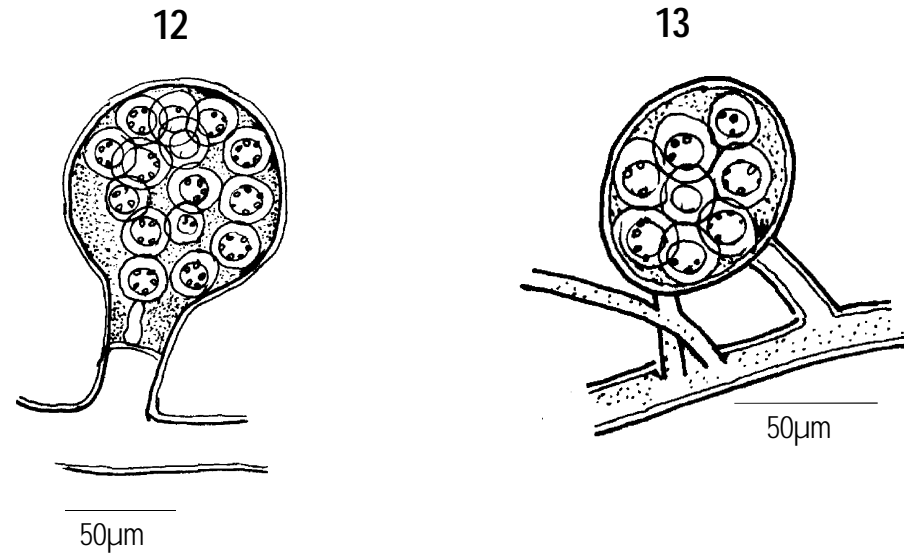

Figures 1-13. Saprolegina anomalies sp. nov.

1 - The hypha showing branching; 2-3 - Elongated zoosporangia; 4 - Proliferating zoosporangium; 5 - Empty zoosporangium with zoospore release tubes; 6-7 - Morphological variations in gemmae; 8-9 - Empty gemmae with zoospore releasing tube; 10 - Zoospores; 11 - Oogonium with diclinous antheridia; 12 - Oogonium with hypogynous antheridium;

13 - Oogonium with monoclinous antheridium 
14

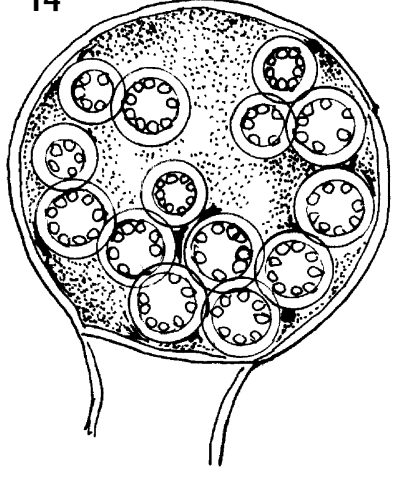

$50 \mu \mathrm{m}$
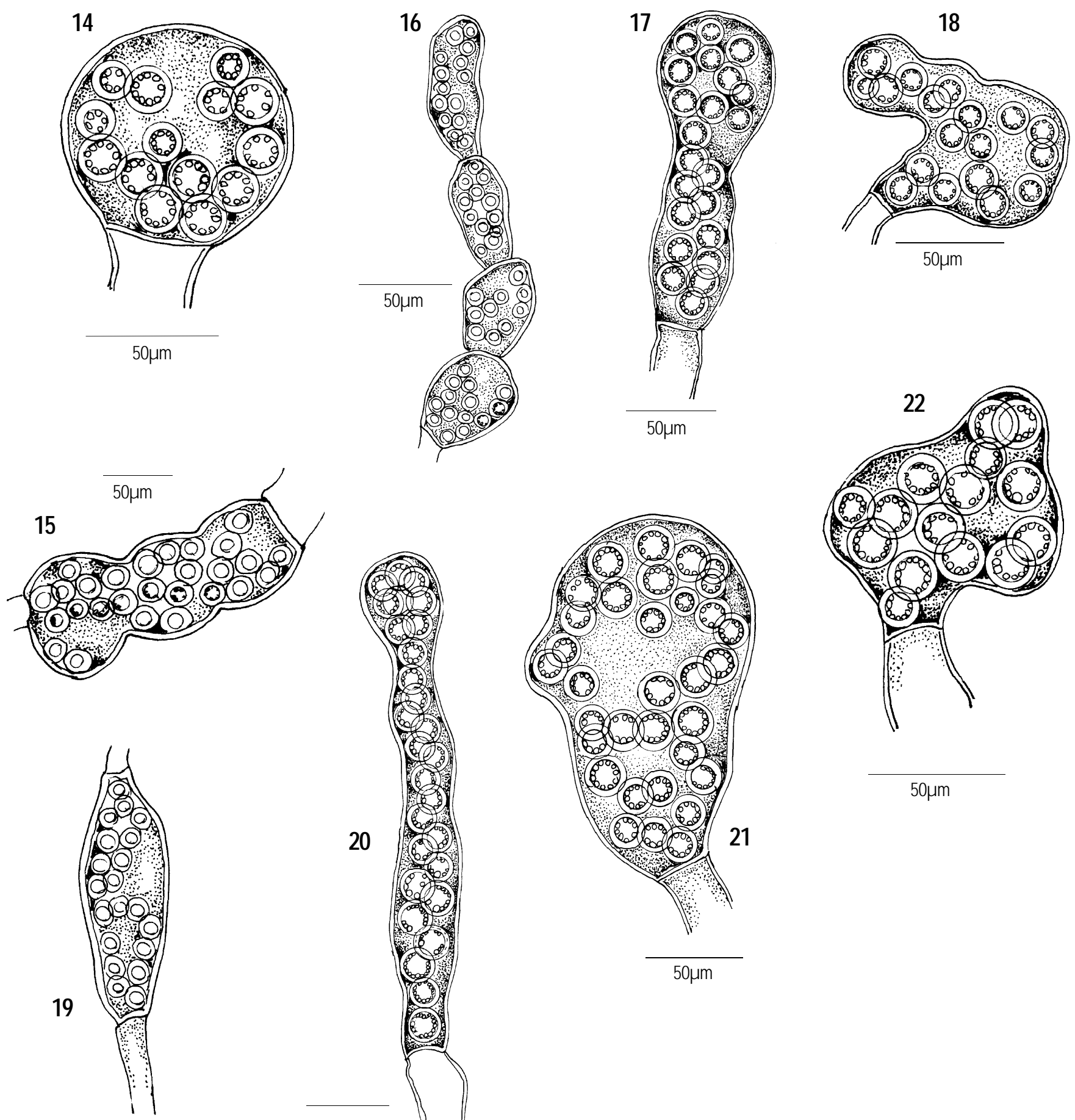

$50 \mu \mathrm{m}$
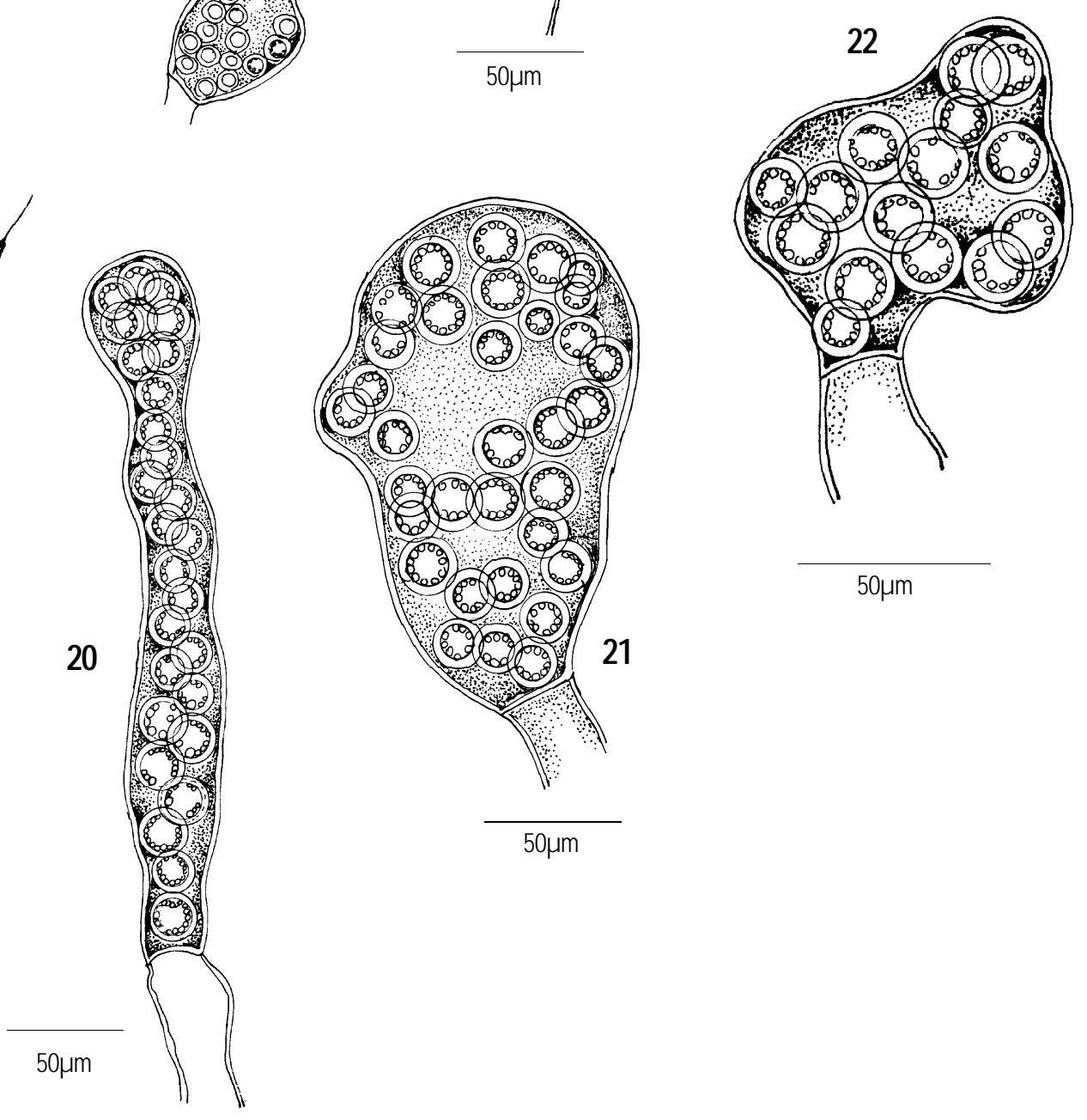

$50 \mu \mathrm{m}$

Figures 14-22. Saprolegina anomalies sp. nov.

14-22 - Oogonia with morphological variations with centric oospores. 
frequens irregularis, terminals ad intercalary, catenulatus. Oospores numero 5-10, centrici, 19-25 um diam. Antheridialis abundans, diclinus, raro monoclinus, hypogynous.

The growth in culture radially symmetrical, hyaline, developing into a colony of $1 \mathrm{~cm}$ within a week on sterilized baits.

Mycelium very stout at the base up to $56-87 \mu \mathrm{m}$ in diameter, gradually tapering at the apex up to $19-31 \mu \mathrm{m}$, branched frequently almost from the base. Zoosporangia numerous, conspicuous, clavate or naviculate, often elongate, usually broader than the hyphal diameter, $400-640 \mu \mathrm{m}$ or more in length, $48-64 \mu \mathrm{m}$ in diameter, proliferating, often vary morphologically. Zoospores many, roughly round, $9-11 \mu \mathrm{m}$ in diameter, often released singly from zoosporangia through conspicuous tubes, swarm for sometime then get encysted. Gemmae abundant, variable in shape and size, intercalary or terminal, globular, spherical, cylindrical to irregular shapes, single and / or very frequently catenulate, short or long stalked, sometimes associated and in continuation with oogonia, 74-651 $\mu \mathrm{m}$ long and 43 to $105 \mu \mathrm{m}$ in diameter, often get converted into sporangia. Zoospores released by the formation of tube or tubes from the

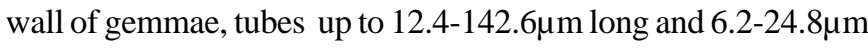
in diameter, zoospores escape singly with fast rate from the conspicuous tubes. Oogonia limited in number, terminal or intercalary, oval, spherical, cylindrical, elliptical, in addition variable in shape and size catenulate, stalked or sessile, sometimes attached to gemmae, proliferation frequent, smooth walled, pits seen only at the antheridial attachment, $43.4-80 \mu \mathrm{m}$ in diameter. Oospore number is remarkably variable, 4-50 in number or more, not filling completely the oogonial cavity, centric, 18.6-24.8 $\mu \mathrm{m}$ in diameter. Antheridial branches abundant, mostly diclinous, rarely monoclinous, hypogynous, laterally or apically appressed or with projections, not covering the oogonia from all the sides.

\section{Discussion}

The proposed new species $S$. anomalies appears to be closely related to $S$. anisospora and $S$. diclina primarily in type of zoosporangia, oogonia, antheridia and gemmae as shown in the Table 1, but widely differs because of several remarkable morphological abnormalities of zoosporangia, oogonia and gemmae. All these structures developed with a very great frequency at the very earlier stage of the culture as these abnormalities are the characteristics of the species. Variously shaped gemmae are abundant often intercalary or terminal in position with short or long catenations, which are more or less similar to that of $S$. anisospora de Bary. The described species also develops frequent and more common proliferated zoosporangia similar to that of $S$. anisospora. However, in the present species more frequent and wide morphological variations are obtained than any other species of Saprolegnia so far described. These zoosporangia are remarkably varied in shapes -- spherical, elongated or very irregular. They are very frequently developed by the proliferated gemmae from any portion. Very often zoosporangia develop one or more tubes of various lengths for the release of zoospores. However, zoospores are of only one type and dissimilar to that of two types of zoospores in S. anisospora. In a developing culture of the new species, mostly oogonia are developed very late, and very frequently, by the proliferation of the gemmae. These oogonia are with very wide range of morphological variations showing some similarities to the allied species $S$. anisospora. The described species mainly differs from the other species by developing several eggs in variously proliferated oogonia. However, the diameter of the eggs remarkably differs in different oogonia. Another species $S$. diclinous mainly differs from the present species by developing only diclinous antheridia. The new proposed species developed both monoclinous as well as diclinous antheridia in the same culture. In view of the above mentioned differences the new species is proposed. The culture of the species requires nucleotide analyses for interrelationships and phylogeny.

\section{Acknowledgement}

The authors are grateful to the authorities of Modern College, Pune, for providing laboratory facilities.

\section{References}

Butler, E.J. (1907). An account of the genus Pythium and some Chytridiaceae. Hem. Department of Agriculture, India. Botanical Series 1: $1-160$.

Coker, W.C. (1923). The Saprolegniaceae with Notes on other Water Moulds. University North Carolina Press. Chapel Hill, North Carolina.

Dayal, R. and U. Kiran (1988). Zoosporic fungi of India. Inter India Publication. New Delhi. 297pp.

Dick, M.W. (1973). Saprolegniales, pp.113-144. In: Ainsworth, G.C., F.K. Sparrow and A.S. Sussaman (Eds.). The Fungi. An Advanced Treatise. Academic Press, New York.

Johnson, S.J. (1956). The Genus Achlya Morphology and Taxonomy. University Michigan Press, Ann Arbor, Michigan, 180pp.

Khulbe, R.D. (2001). A Manual of aquatic fungi (Chyridiomycetes and Oomycetes). Daya Publishing House, Delhi. pp.1-204.

Sparrow, F.K. (1960). Aquatic Phycomycetes. The University of Michigan Press, Ann Arbor, Michigan.

Sparrow, F.K. Jr.(1968). Ecology of fresh water fungi, pp. 95-105. In: Ainsworth, G.C. and A.S. Sussaman (Eds.). The Fungi. An Advanced Treatise. Academic Press, New York.

Sparrow, F.K. Jr. (1973). Mastigomycotina (Zoosporic Fungi) 6173pp. In: Ainsworth, G.C., F.K. Sparrow and A.S. Sussaman (Eds.). The Fungi. An Advanced Treatise Vol. VIB. Academic Press, New York. 
Table 1. Comparison of the Saprolegnia anomolies sp. nov. with allied species of Saprolegnia

\begin{tabular}{|c|c|c|c|}
\hline & S. anisospora & S. diclina & S. anomalies sp. nov. \\
\hline Hyphae & $\begin{array}{l}\text { Not branched from the base, } 16-33 \mu \mathrm{m} \\
\text { at base }\end{array}$ & $\begin{array}{l}\text { Not branched from the base, } 12-68 \mu \mathrm{m} \\
\text { at base }\end{array}$ & $\begin{array}{l}\text { Branched from the base, clustered branching, } \\
55.8-86.8 \mu \mathrm{m} \text { at base. }\end{array}$ \\
\hline Zoosporangia & $\begin{array}{l}\text { Elongated, cylindrical, } \\
13-33 \times 66-330 \mu \mathrm{m} \\
\text { Dictyosporangia present }\end{array}$ & $\begin{array}{l}\text { Cylindrical, } 25-85 \times 45-660 \mu \mathrm{m} \\
\text { Dictyosporangia absent }\end{array}$ & $\begin{array}{l}\text { Variously shaped, zoospores released by } \\
\text { tube formation. } 48-64 \text { x } 400-640 \mu \mathrm{m} \text {. } \\
\text { Dictyosporangia absent }\end{array}$ \\
\hline Gemmae & $\begin{array}{l}\text { Few, variously shaped often converted. } \\
\text { into sporangia, emptying by } \\
\text { a conspicuous tube }\end{array}$ & $\begin{array}{l}\text { Abundant, longer ones are the characteristic } \\
\text { of this species, not converted into sporangia }\end{array}$ & $\begin{array}{l}\text { Abundant, variously shaped, often converted } \\
\text { into sporangia, emptying by a conspicuous } \\
\text { tube. }\end{array}$ \\
\hline Zoospores & $\begin{array}{l}\text { Spores are of two kinds, smaller ones } \\
8-9 \mu \mathrm{m} \text { in diameter, larger ones } \\
13.7-14.8 \mu \mathrm{m}\end{array}$ & $\begin{array}{l}\text { Spores are of one kind, } 9.5-11 \mu \mathrm{m} \text { in } \\
\text { diameter, usually } 10-12 \mu \mathrm{m} \text {. }\end{array}$ & $\begin{array}{l}\text { Spores are of one kind, } 9.1-10.92 \mu \mathrm{m} \text { in } \\
\text { diameter. }\end{array}$ \\
\hline Oogonia & $\begin{array}{l}\text { Abundant, typically spherical, oval to } \\
\text { pear, oblong, spindle shaped, thick-walled, } \\
\text { beneath each antheridium distinct circular } \\
\text { pit. } 49.5-92.5 \mu \text { m in diameter. }\end{array}$ & $\begin{array}{l}\text { Abundant, spherical or oval or pear shaped, } \\
\text { catenulate, thin-walled, without pits except } \\
\text { where antheridia attached.50-70 } \mu \mathrm{m} \text { in } \\
\text { diameter. }\end{array}$ & $\begin{array}{l}\text { Numerous, very irregular in morphology, } \\
\text { thin-walled, without pits except } \\
\text { where antheridia attached. } 43.4-80 \mu \mathrm{m} \text { in } \\
\text { diameter. }\end{array}$ \\
\hline Oospores & $\begin{array}{l}\text { Eccentric or subcentric, filling the } \\
\text { oogonium completely, } 1 \text { to } 20 \text { in number, } \\
19.8-23.1 \mu \text { m in diameter. }\end{array}$ & $\begin{array}{l}\text { Centric, 1-40 usually 4-18 in number, } \\
20-23.5 \mu \mathrm{m} \text { in diameter. }\end{array}$ & $\begin{array}{l}\text { Centric, not filling the oogonial cavity } \\
\text { completely, } 4-50 \text { in number or more. } \\
\text { 18.6-24.8 } \mathrm{m} \text { in diameter. }\end{array}$ \\
\hline Antheridia & Diclinous & $\begin{array}{l}\text { Diclinous } \\
\text { hypogynous }\end{array}$ & Diclinous, rarely monoclinous and \\
\hline
\end{tabular}

